\title{
Asian Crops Overview: Consumer Preference and Cultivar Growth on the East Coast of the United States
}

\author{
William J. Sciarappa ${ }^{2}$, Jim Simon, Ramu Govindasamy, Kathleen Kelley, Frank Mangan, Shouan Zhang, \\ Surendran Arumugam, Peter Nitzsche, Richard Van Vranken, Stephen Komar, Albert Ayeni, Gene McAvoy, \\ Chung Park, William Reichert, David Byrnes, Qingli Wu, and Brian Schilling \\ Department of Agriculture and Resource Management Agents, New Jersey Agricultural Experiment Station, Rutgers \\ University, New Brunswick, NJ 08903 \\ Ricardo Orellana ${ }^{1}$ \\ University of Massachusetts, Amherst, MA 01003
}

Additional index words. Asian vegetables, Asian demographics, specialty crops, herbs

\begin{abstract}
The rapid expansion of Asian populations in the United States presents significant opportunities and challenges for the eastern U.S. produce sector to take advantage of their close proximity to densely populated areas. Initial crop studies followed by ethnic consumer and crop surveys were conducted to examine vegetable, leafy green, and herb consumption and expenditures among Chinese, Asian Indians, and other Asian groups. Consumer choices were used to prioritize subsequent production trials. Family expenditures were determined for specific Asian produce types and total produce purchases. This market data were extrapolated to the east coast Asian populations to assess potential market size ( $90 \%$ confidence interval, error margin $5.6 \%)$. Chinese consumer values ranged from \$245 to \$296 million per annum and Asian Indians ranged from \$190 to \$230 million per annum. The average annual fresh fruit and vegetable expenditures by both Asian groups were 2 to 3.5 times respective national averages. Leading Chinese vegetables determined by average expenditures were baby bok choy, pak choy, oriental eggplant, snow pea, oriental spinach, and napa cabbage. Highest expenditure of leafy greens and herbs for Chinese consumers were chives and garland chrysanthemum. This marketdriven survey reported consumption of over 100 Asian crops and 42 cultivars were ranked "feasible" to grow in the eastern section of the United States. Horticultural matrices of selection criteria narrowed the list to the most promising candidates for production. As a result, 28 cultivars were then grown in University research and demonstration plots at Massachusetts, New Jersey, and Florida in determining growth characteristics and yield to focus horticultural crop producers. Leading vegetable cultivars for Asian Indian consumers were bitter gourd, eggplant, fenugreek leaves, cluster beans, and bottle gourd. Leading leafy greens and herbs for Asian Indians were turmeric, fenugreek, sorrel spinach, and radish greens. Most of these Asian cultivars were demonstrated to grow well in the three main growing zones of 5, 7, and 9. Phytochemical attributes such as antioxidant activity, polyphenols, and mineral contents were analyzed for several of the leading crop candidates. This initial field and laboratory data shows that many of these ethnic crops can be grown in the eastern United States to direct production opportunities and are nutrient rich to help drive consumer demand.
\end{abstract}

Economic opportunities have arisen for specialty agriculture catering to ethnically diverse consumers along the eastern coast of the

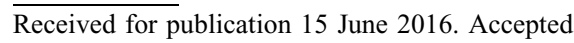
for publication 22 July 2016

This paper was part of the colloquium "Alternative Specialty Crop: Opportunities and Challenges," presented at the 2015 ASHS Conference, New Orleans, LA, on 4 Aug. 2015, and sponsored by the Working Group of Asian Horticulture, Tropical Horticulture Working Group, and Pomology Working Group.

This project was supported by the Specialty Crop Research Initiative of the National Institute of Food and Agriculture, U.S. Department of Agriculture (USDA), Grant no. 2009-51181-06035, and by the National Research Initiative (NRI) of the Cooperative State Research, Education and Extension Service, USDA, Award no. 2005-35618-15735. Funding and support was also provided by the New Jersey Agricultural Experiment Station, the Rutgers Cooperative Extension Service, and the New Jersey Farm Bureau. We thank our university program assistants for crop culture and harvest and the New Use Agriculture and Natural Plant Products for their support in nutritional analyses and phytochemistry.

The opinions expressed in the article are those of the authors and do not necessarily reflect official positions or policies of the USDA, Rutgers University, Pennsylvania State University, University of Florida, or University of Massachusetts.

${ }^{1}$ Current address: Inter-American Institute for Cooperation on Agriculture, San Lorenzo, Paraguay. ${ }^{2}$ Corresponding author. E-mail: sciarappa@njaes. rutgers.edu.
United States (Tubene, 2001). U.S. Census data shows that the overall average American population increases from 2000 to 2012 were $9.5 \%$ as compared with $32 \%$ for the subgroup of Asians (U.S. Census Bureau, 2011). U.S. Census data (2011) had shown that the mainstream population of this eastern region increased by $13 \%$ from 1990 to 2000 as compared with $48 \%$ for Asian populations. Total U.S. Asian populations are expected to rise to $\approx 25$ and 40 million people by 2030 and

Table 1. East coast study area and Asian populations per state 2014-U.S. Census data.

\begin{tabular}{lccr}
\hline State & $\begin{array}{c}\text { Total population } \\
\text { (estimate) }\end{array}$ & $\begin{array}{c}\text { \% Asian } \\
\text { population }\end{array}$ & $\begin{array}{r}\text { Total Asian } \\
\text { population }\end{array}$ \\
\hline Connecticut & $3,596,677$ & 4.5 & 161,850 \\
Delaware & 935,614 & 3.8 & 35,553 \\
Florida & $19,893,297$ & 2.8 & 557,012 \\
Georgia & $10,097,343$ & 3.8 & 383,699 \\
Maine & $1,330,089$ & 1.2 & 15,961 \\
Maryland & $5,976,407$ & 6.4 & 382,490 \\
Massachusetts & $6,745,408$ & 6.3 & 424,961 \\
New Hampshire & $1,326,813$ & 2.5 & 33,170 \\
New Jersey & $8,938,175$ & 9.4 & 840,188 \\
New York & $19,746,227$ & 8.5 & $1,678,429$ \\
North Carolina & $9,943,964$ & 2.7 & 268,487 \\
Pennsylvania & $12,787,209$ & 3.3 & 421,978 \\
Rhode Island & $1,055,173$ & 3.5 & 36,931 \\
South Carolina & $4,832,482$ & 1.5 & 72,487 \\
Vermont & 626,562 & 1.6 & 10,025 \\
Virginia & $8,326,289$ & 6.3 & 524,556 \\
Washington DC & 658,893 & 4.0 & 26,356 \\
Total & $116,816,622$ & 5.1 & $5,874,135$ \\
\hline
\end{tabular}

2050 , respectively. The ethnic population boom from 1990 to 2005 along the east coast was even more pronounced where Asian population hubs in the northeast region reached $60 \%$ growth or more during this period (Govindasamy et al., 2007c). With large Asian populations in New York City, Newark, Baltimore, and Washington D.C., local growers can adopt new ethnic crops to engage these emerging markets.

By identifying new specialty vegetables, greens, and herbs that can be grown economically 
on the east coast, our concept was to connect more precisely with consumer interest which mitigates grower risk and creates more opportunities for local agricultural production. We hypothesized that if ethnic consumers were searching for and/or purchasing specific fresh horticultural produce, this rising demand provides alternative production options for U.S. farmers to grow new crops that are not easily found in the traditional markets in their region.

The overall objective was to focus on the ethnic produce market segments along the east coast where Chinese and Asian Indian consumers were chosen to survey for their strong recent growth and continued growth expectations (Govindasamy et al., 2007a, 2007b, 2007c, 2010a, 2010b, 2014). This demographic approach applied market survey results of consumer preference to identify and prioritize crop types of specific Asian cultivars for research investigation and commercial demonstration.

University extension trials continue to work on production practices for these new crop introductions (Ayeni et al., 2010a, 2010b, 2010c; Mangan et al., 2012; Park et al., 2007; Sciarappa 2003; Sciarappa et al., 2004a, $2004 b$ ). Local farmers can benefit from targeting food crops in higher demand and catering to the special culinary needs of this sizable ethnic market as well as expanding local production into Asian markets and penetrating established mainstream institutions (Govindasamy et al., 2010a, 2014a).

Market penetration of new food crops can be improved by documenting human health functionality by noting native properties of the produce (Goldman, 2014). Recent research efforts have begun to better understand phytonutrient content of vegetable crops (Newell-McGloughlin, 2008). Concurrently, more consumers are choosing foods with suspected health benefits and

Table 2. Chinese produce ranking for consumer frequency and volume of specific produce purchased based on average weekly expenditure (\$) - Govindasamy et al. (2007).

\begin{tabular}{|c|c|c|c|c|c|c|c|}
\hline \multirow[b]{2}{*}{ Produce } & \multicolumn{6}{|c|}{ Rank based on criteria (weekly purchases) } & \multirow{2}{*}{$\begin{array}{l}\frac{\text { Expenditure }}{\text { Avg exp }^{z}} \\
\text { (includes all } \\
\text { respondents) }\end{array}$} \\
\hline & $\begin{array}{l}\text { Avg exp } \\
\text { (includes all } \\
\text { respondents) }\end{array}$ & $\begin{array}{c}\text { Avg exp }{ }^{y} \\
\text { (purchasers only) }\end{array}$ & $\begin{array}{c}\text { Produce } \\
\text { purchase } \\
\text { frequency/week }\end{array}$ & $\begin{array}{l}\text { Volume of } \\
\text { produce } \\
\text { bought }\end{array}$ & Avg rank & Overall rank & \\
\hline Baby pak choy & 1 & 1 & 2 & 2 & 1.5 & 1 & $\$ 2.26$ \\
\hline Oriental eggplant & 3 & 2 & 5 & 4 & 3.5 & 3 & $\$ 1.60$ \\
\hline Snow peas & 4 & 4 & 6 & 6 & 5 & 4 & $\$ 1.29$ \\
\hline Oriental spinach & 5 & 7 & 4 & 5 & 5.25 & 5 & $\$ 1.28$ \\
\hline Edamame & 8 & 8 & 7 & 9 & 8 & 8 & $\$ 0.79$ \\
\hline Oriental mustard & 9 & 9 & 9 & 8 & 8.75 & 9 & $\$ 0.71$ \\
\hline Malabar spinach & 11 & 6 & 12 & 12 & 10.25 & 10 & $\$ 0.20$ \\
\hline Basil & 10 & 12 & 10 & 10 & 10.5 & 11 & $\$ 0.22$ \\
\hline Perilla & 12 & 11 & 11 & 11 & 11.25 & 12 & $\$ 0.19$ \\
\hline
\end{tabular}

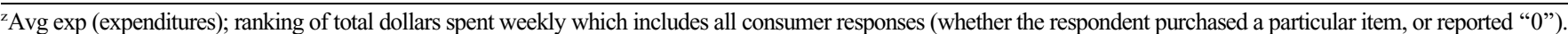

"Avg exp (expenditures); ranking of total dollars spent weekly which includes only consumers who purchased the item (excludes purchases equal to "0").

Table 3. Indian produce ranking for consumer frequency and volume of specific produce purchased based on average weekly expenditure (\$)-Govindasamy et al. (2007).

\begin{tabular}{|c|c|c|c|c|c|c|c|}
\hline \multirow[b]{2}{*}{ Produce } & \multicolumn{6}{|c|}{ Rank based on criteria (weekly purchases) } & \multirow{2}{*}{$\begin{array}{l}\frac{\text { Expenditure }}{\text { Avg exp }} \\
\text { (includes all } \\
\text { respondents) }\end{array}$} \\
\hline & $\begin{array}{l}\text { Avg exp } \\
\text { (includes all } \\
\text { respondents) }\end{array}$ & $\begin{array}{c}\text { Avg exp }{ }^{y} \\
\text { (purchasers only) }\end{array}$ & $\begin{array}{l}\text { Produce purchase } \\
\text { frequency }\end{array}$ & $\begin{array}{c}\text { Volume of } \\
\text { produce bought }\end{array}$ & Avg rank & Overall rank & \\
\hline Bitter gourd & 1 & 2 & 3 & 2 & 2 & 1 & $\$ 2.48$ \\
\hline Eggplant & 2 & 6 & 1 & 1 & 2.5 & 2 & $\$ 2.23$ \\
\hline Fenugreek leaves & 3 & 8 & 2 & 3 & 4 & 3 & $\$ 1.48$ \\
\hline Cluster beans & 4 & 3 & 6 & 5 & 4.5 & 4 & $\$ 1.33$ \\
\hline Bottle gourd & 5 & 7 & 5 & 4 & 5.25 & 5 & $\$ 1.31$ \\
\hline Mustard leaves & 6 & 1 & 8 & 7 & 5.5 & 6 & $\$ 1.06$ \\
\hline Ridge gourd & 7 & 5 & 7 & 6 & 6.25 & 7 & $\$ 0.94$ \\
\hline Mint leaves & 8 & 10 & 4 & 8 & 7.5 & 8 & $\$ 0.68$ \\
\hline Amaranth & 9 & 4 & 10 & 10 & 8.25 & 9 & $\$ 0.61$ \\
\hline White pumpkin & 10 & 9 & 9 & 9 & 9.25 & 10 & $\$ 0.56$ \\
\hline
\end{tabular}

${ }^{2}$ Avg exp (expenditures); ranking of total dollars spent per week which includes all consumer responses (whether the respondent purchased a particular item, or reported "0").

${ }^{y}$ Avg exp (expenditures); ranking of total dollars spent per week which includes only consumers who purchased the item (excludes purchases equal to 0 ).

Table 4. Asian ethnic produce market estimates-Govindasamy et al. (2007).

\begin{tabular}{|c|c|c|}
\hline Survey sample data & Chinese & Indian \\
\hline SD (produce expenditure/year/person) & $\$ 319$ & $\$ 287$ \\
\hline SE (produce expenditure/year/person) & $\$ 22$ & $\$ 19$ \\
\hline Upper bound $\left(90 \% \mathrm{CI}^{2}\right)$ & $\$ 421$ & $\$ 357$ \\
\hline Margin of error $(90 \% \mathrm{CI})$ & $5.64 \%$ & $5.37 \%$ \\
\hline Produce market estimates & & \\
\hline East coast produce market estimate; lower bound $(90 \% \mathrm{CI})$ & $\$ 245,255,771$ & $\$ 190,308,137$ \\
\hline Upper bound $(90 \% \mathrm{CI})$ & $\$ 295,679,025$ & $\$ 230,079,604$ \\
\hline Margin of error $(90 \% \mathrm{CI})$ & $5.64 \%$ & $5.37 \%$ \\
\hline
\end{tabular}

Expenditure estimate for ethnic population mean (sample mean $\pm 1.645 \mathrm{SE}$ ).

${ }^{\mathrm{z}} \mathrm{CI}=$ confidence interval. 
superior nutritional qualities (Cappellano, 2009). Increased consumption of a diversity of vegetables in the diet may provide beneficial health outcomes (Bellavia et al., 2013). Several indigenous Asian crops in the Allium (chives), Brassicaceae (broccoli and cabbage), and herb families are associated with medicinal and health properties (Block, 2010; Janick, 2003). The Working Group of Asian Horticulture held a workshop entitled 'Asia's Indigenous Horticultural Crops' at the 2009 annual conference of the American Society of Horticultural Scientists to share research information and increase awareness among members (Mou and Wang, 2012). Similarly, this paper from the 2015 Working Group of Asian Horticulture Colloquium presents highlights to illustrate the use of a market-first analysis of new crops to determine research steps targeting ethnic consumers and crop producers.

\section{MATERIAL AND METHODS}

Rutgers University-New Jersey Agricultural Experiment Station led an Ethnic Vegetable Team bringing together research and extension personnel from the land-grant universities of New Jersey, Florida, Massachusetts, and Pennsylvania. U.S. Census data were used to develop demographic information for the east coast populations from Maine to Florida. A private firm, Wats Room Inc., was outsourced to conduct phone interviews with computer-assisted telephone interview technology to survey a statistically significant sample of the Asian population per state. Bilingual consumer surveyors speaking Mandarin, Cantonese, or Hindi interviewed the principal grocery shopper in each household totaling 685 Asian-Americans in regards to their expenditures for species-specific vegetable and herb purchases. Follow-up questions were developed for smaller focus groups and internet bulletin boards (Govindasamy et al., 2011). From this consumer feedback, market potential was determined for specific Asian vegetables, leafy greens, and herbs which were identified as to species, named in Asian languages, and chosen for their horticultural feasibility in east coast markets. This selection process of leading crop candidates was first conducted as part of the U.S. Department of Agriculture-National Resources Inventory program for Asian vegetables in general and then more specifically as the U.S. Department of Agriculture-Specialty Crop Research Initiative program for the leafy greens and herbs crop group (Govindasamy et al., 2007a). Chaput's field guide was used to identify the species to ensure correct cultivar selection for trials (Chaput, 1998).

This selection process ranked leading Chinese and Asian Indian crops that were grown from 2007 to 2014 in New Jersey, Massachusetts, and Florida. Plasticulture was used in raised beds with trickle irrigation (Sciarappa, 2001) and standard management practices for all cultivars as appropriate for each region. Small plot, replicated trials, and field demonstrations were used to evaluate

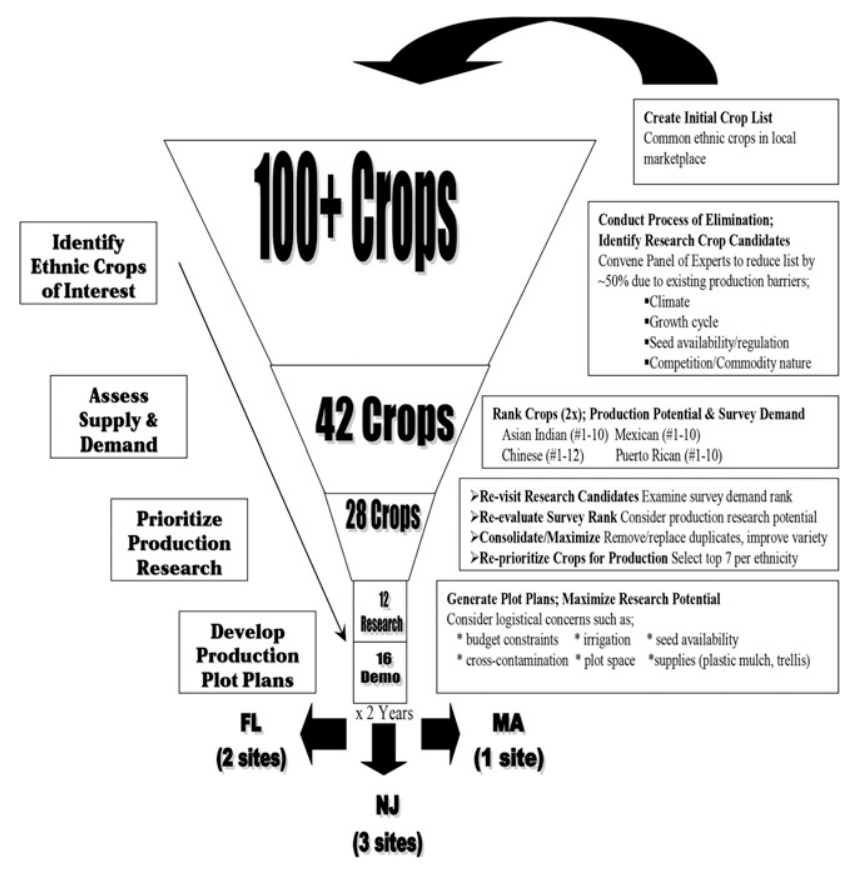

Fig. 1. Selection process for ethnic specialty crops-Govindasamy et al. (2007).

various parameters of morphological features, plant growth, and yield. Features such as plant height, plant spread, and leaf length were measured in $\mathrm{cm}$. Plant uniformity and vigor were both assessed on a $1-5$ scale, which is visually described as $1=$ poor, 2 = marginal, $3=$ fair, $4=$ good, and $5=$ excellent. Since some indigenous Asian cultivars have been shown to provide potential health-promoting properties and have Asian popularity (Molinar, 2012; Patel et al., 2012), especially in the Curcurbitaceae, Fabaceae, Gramineae, Solanaceae, and Cruciferae, a preliminary analysis was conducted for phytochemical composition of a few promising cultivars in east coast trials.

\section{RESULTS AND DISCUSSION}

Demographics. Updated data on populations of Asian-Americans in year 2014 on the Atlantic Coast total 5,874,135 people constituting $5.1 \%$ of the total entire regional population (Table 1). Rapid population growth across the entire United States is expected to continue and total $\approx 40$ million citizens by year 2050. This current and future expansion of Asian populations strengthened our hypothesis that significant opportunities exist for vegetable, leafy green, and herb growers who farm closely to densely populated areas.

Asian crop expenditures. Chinese and Asian Indian consumers showed distinct differences in expenditures for preferred food crops. Chinese consumers spent from $\$ 1.00$ to $\$ 2.20$ /week on baby pak choy, pak choy, oriental eggplant, oriental spinach, snow pea, napa cabbage, and luffa, whereas Asian Indians spent $\$ 1.00$ to $\$ 2.43 /$ week on mustard leaves, bottle gourd, cluster beans, fenugreek leaves, eggplants, and bitter gourd.
Using the criteria of average expenditure, purchase frequency, and volume purchased provided a 1-12 ranking for Chinese vegetable cultivars and a 1-10 ranking for Asian Indian vegetable cultivars (Tables 2 and 3).

Asian market estimation. In the survey of the Asian consumer market segment, a representative sampling of households and individuals interviewed 434 Asians living on the east coast. Ethnic produce expenditures for vegetables per household were extrapolated to estimate the Chinese annual purchases with a range of \$245 to \$296 million and the Asian Indian at \$190 to \$230 million annually within a $90 \%$ confidence interval with a margin of error of $5.6 \%$ or better (Table 4 ). A high percentage had previously indicated a willingness to purchase locally grown produce (Puduri and Govindasamy, 2011).

Asian crop preferences. With leafy greens and herbs, the major Chinese selections preferred by consumers were shanghai bok choy (Brassica rapa var. chinensis), pak choi, and mizuna (Brassica rapa var. chinensis and var. japonica), chinese broccoli (Brassica oleracea), chinese mustard (Brassica juncea), sugar pea (Pisum sativum), chives (Allium shoenoprasum), garland chrysanthemum (Chrysanthemum coronarium), and shepherd's-purse (Capsella bursa-pastoris). Major leafy greens and herbs preferred by east Indian consumers were fenugreek (Trigonella foenium), Indian sorrel (Rumex acetosa), tricolor radish (Raphanus sativa), amaranth (Amaranthus sp.), roselle also called hibiscus (Hibiscus sabdariffa), lemon balm (Melissa officinalis), swiss chard (Beta vulgaris subsp. cycla), and malabar spinach (Basella alba cv. Rubra) (Govindasamy et al., 2014b, 2014c).

Crop selection. Market survey data provided a list of 100 potential Asian crops. Selection criteria winnowed this large group 


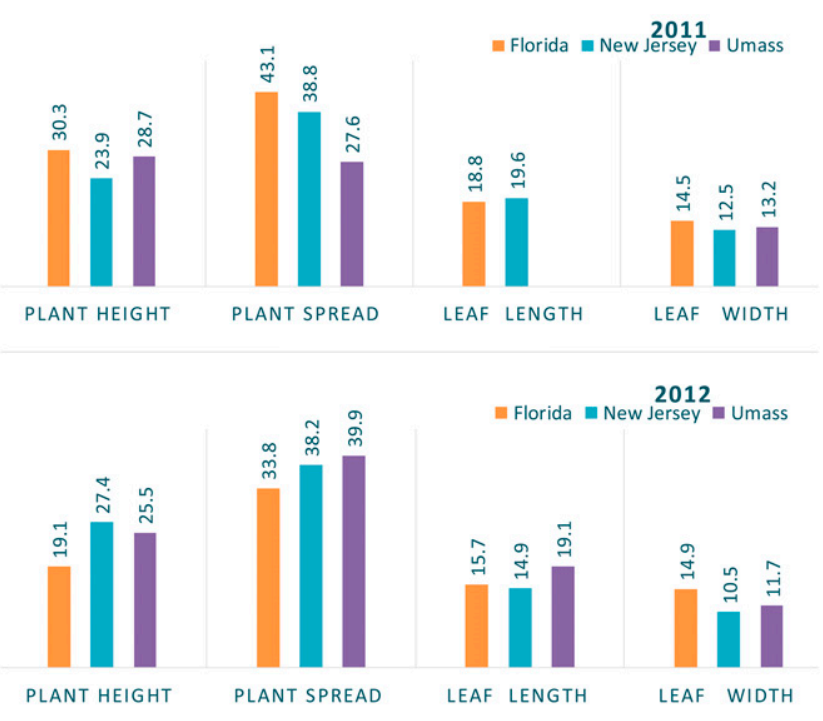

Fig. 2. Bok choy: average morphological characters (in $\mathrm{cm}$ ) from fieldgrown plants in Florida, New Jersey, and University of Massachusetts.
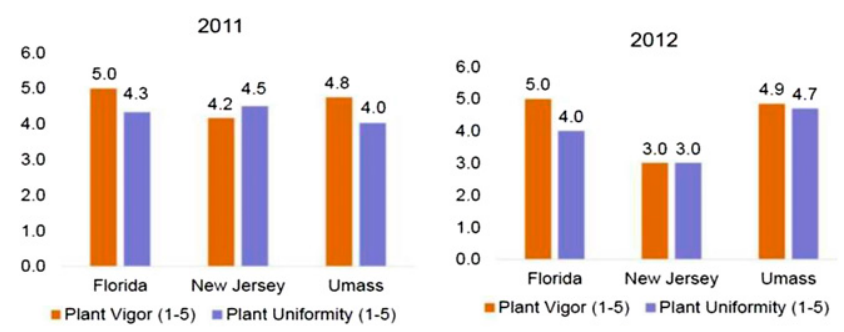

Fig. 3. Bok choy: plant uniformity and plant vigor (scale: 1-5) over 2 years and three locations, Florida, New Jersey, and University of Massachusetts.

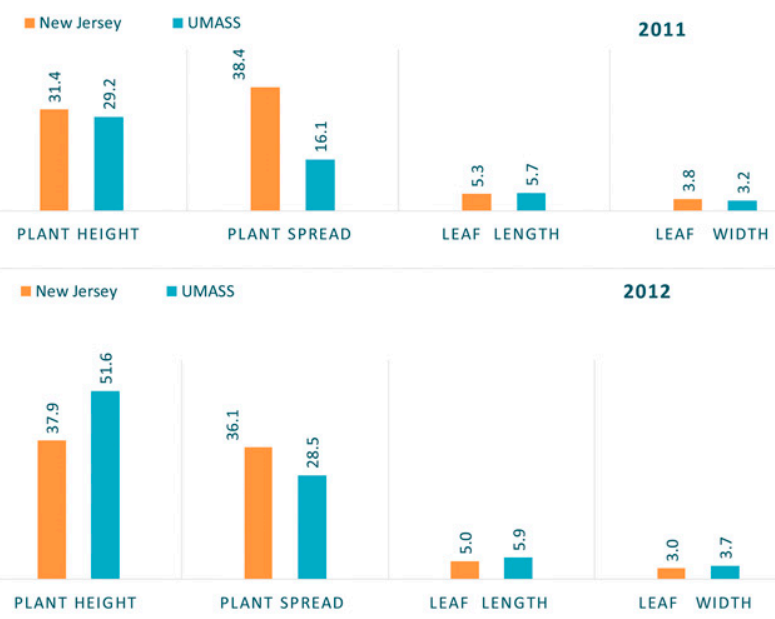

Fig. 4. Sugar pea: average morphological characters (in $\mathrm{cm}$ ) from fieldgrown plants in New Jersey, and University of Massachusetts, in 2011 and 2012.

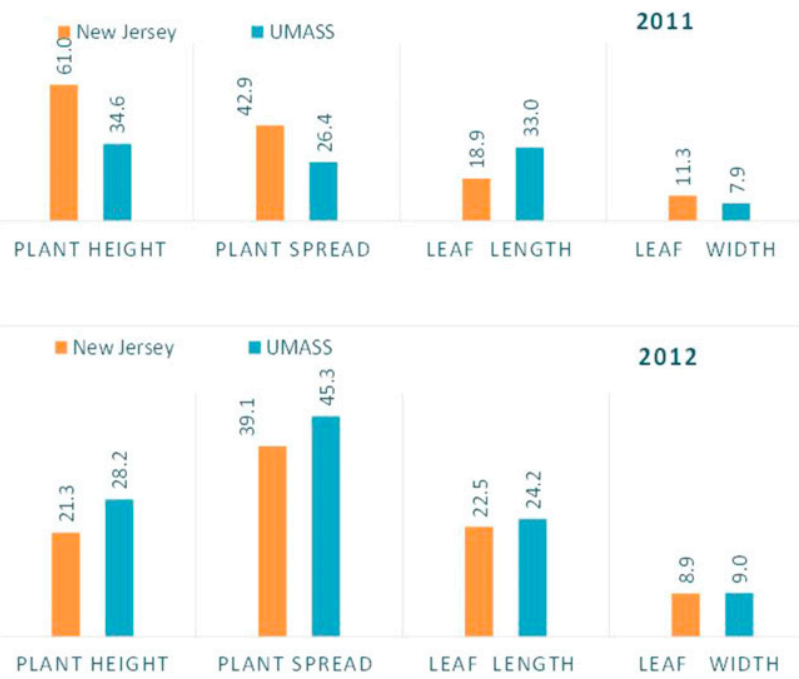

Fig. 5. Indian sorrel spinach: average morphological characters (in $\mathrm{cm}$ ) from field-grown plants in New Jersey, and University of Massachusetts. down to 28 key crops for horticultural evaluation. Of those, 12 key crops were delegated for demonstrational trials and 16 for replicated field trials over 2 years in each three states (Fig. 1).

Horticultural assessments. Direct comparisons of the field production for ethnic crops over 2 years in multiple locations were challenging due to differences in timing, climatic variation, and more. Since the main goal was to identify market demand and to determine whether selections can be grown in each state, reach maturity, and be commercially grown, a few highlights are presented. Representative examples of various production parameters show chinese bok choy growing consistently well in Florida, New Jersey, and Massachusetts in year 2011 and similarly for 2012, except for New Jersey dropping 1-2 points lower in both plant vigor and uniformity (Figs. 2 and 3). Chinese sugar pea and indian sorrel in New Jersey and Massachusetts grew sufficiently well in both
2011 and 2012 in terms of plant height, plant spread, leaf length, and leaf width (Figs. 4 and 5). Fresh weight yields of indian sorrel spinach were similar for both years in New Jersey and Massachusetts, averaging 144.4 and 83.3 compared with 175.3 and 84.7 g per plant respectively, whereas Florida had very different results. Comparisons of vegetables, greens, or herbs grown in specific regions may vary among other regions. This sitespecific data are necessary for local growers to review and decide which cultivars and yields are economically viable for commercial production.

Amaranth profile. Amaranth was among the most promising new ethnic crops and in demand despite the reluctance of many growers to consider this plant as a crop rather than as a weed. These horticulturally bred cultivars may need to be considered as potentially invasive species. Current agricultural methods such as crop rotation, cultivation, and herbicide use that are used for wild weed species such as redroot pigweed, Amaranthus retroflexus, should suffice if a field was not managed properly and allowed to go to seed.

Amaranth plant height, spread, and leaf length and width were consistent within the three regions and grew well for both years in New England, the Mid-Atlantic, and the southeast (Fig. 6). A similar trend was measured for plants uniformity and vigor (Fig. 7). Nonetheless, yield comparisons were significantly different with the selected cultivar having high consistent weights of 372.7 and $326.6 \mathrm{~g}$ per plant in New Jersey for years 2011 and 2012, respectively, whereas fresh harvest weights in Florida and Massachusetts averaged far lower by large margins ranging from $\approx 2 \times$ to $8 \times$ less (Fig. 8 ). The cause for higher yield in New Jersey is unclear and more applied studies are needed as to fertility levels, soil type, pest control, and climate differences to develop better recommendations and protocols. 


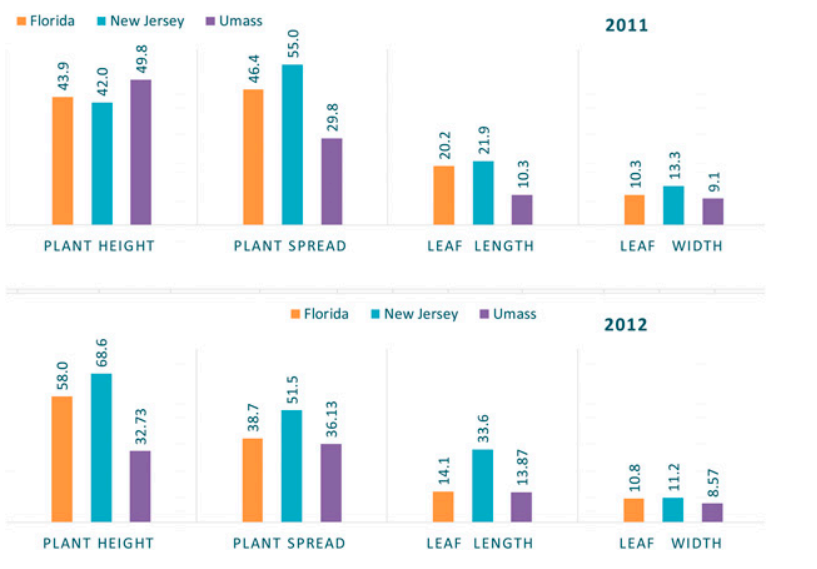

Fig. 6. Amaranth: average morphological characters (in $\mathrm{cm}$ ) from fieldgrown plants in Florida, New Jersey, and University of Massachusetts in 2011 and 2012.

2011

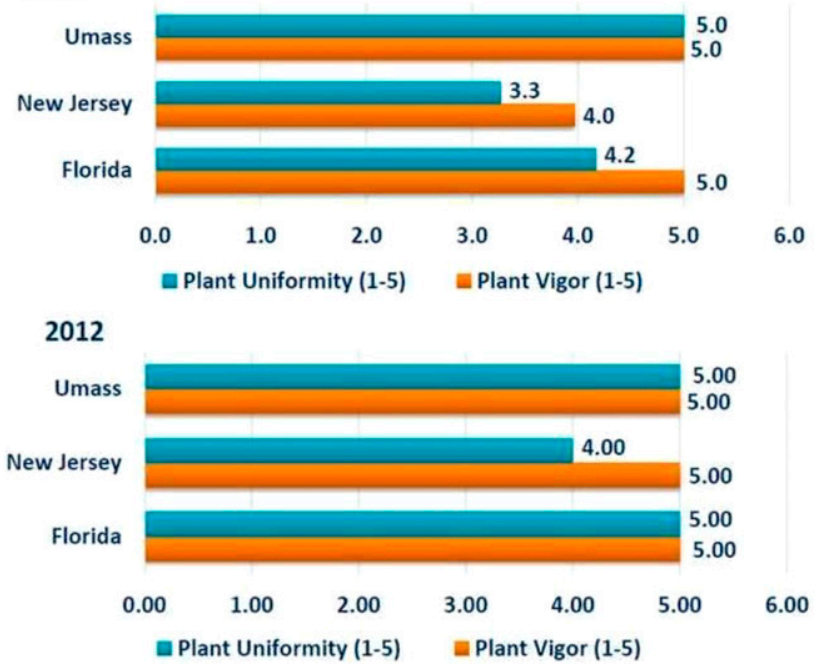

Fig. 7. Amaranth: plant uniformity and plant vigor (scale: $1-5$ ) over 2 years and 3 locations, Florida, New Jersey, and University of Massachusetts.

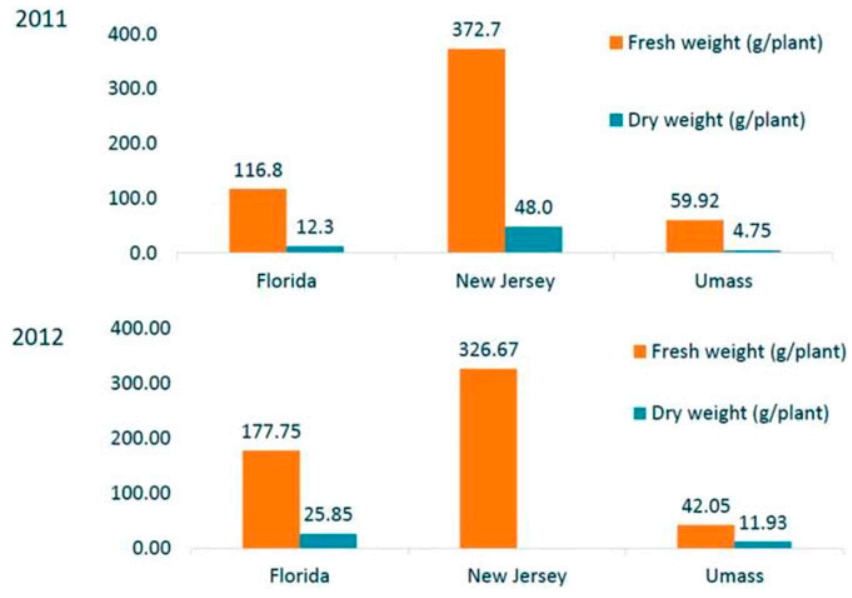

Fig. 8. Amaranth: fresh weight and dry weight (grams/plant).

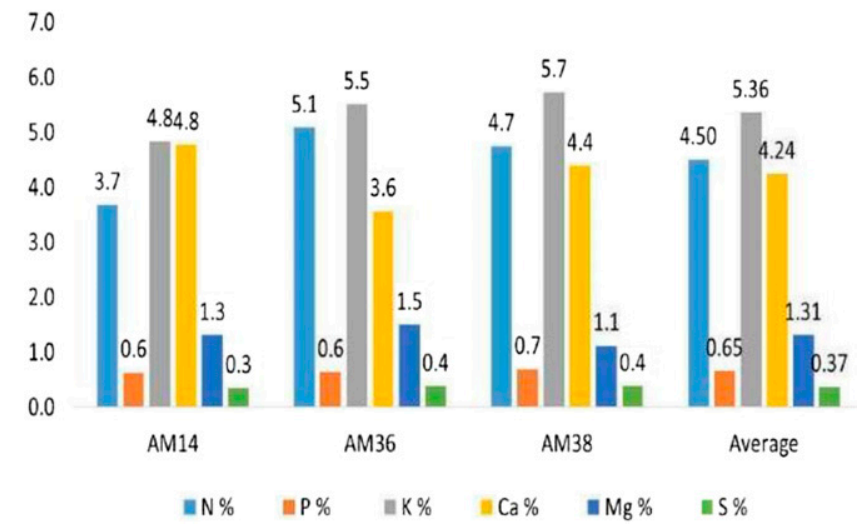

Fig. 9. Amaranth: nutritional value of high-yielding varieties field-grown in New Jersey.
Phytochemistry. In addition to taste and visual appearance, today's healthy choice for food calls for increased nutritional value from eating a diversity of horticultural crops. Mainstream consumers may find expanded even better choices from ethnic Asian vegetable, leafy green, and herb cultivars. Several Asian crops were identified that can be easily grown in a similar manner now employed by growers with other horticultural produce. Nutritional analysis showed these crops to be nutrient dense and a rich source of minerals and vitamins (Table 5). Examples of more detailed phytochemical analysis include amaranth and edamame cultivars. The average value for the top three amaranth varieties selected for high yield had $5.4 \%$ content for nitrogen, $5.36 \%$ for potassium, and $4.24 \%$ for calcium with significant differences among them (Fig. 9; Table 5).

In edamame soy, the isoflavones, daidzein, genistein, glycitein, and their derivatives were found to be the main phenolic compounds. These phytoestrogen compounds show striking similarity to the human estradiol and have exhibited bioactivity to lower the risk of cancer, heart disease, osteoporosis, and relief of menopause symptoms. Four of 10 hydrolized edamame cultivars showed $0.1 \%$ content or greater of isoflavones (Shen et al., 2011) with a diversity of molecular structures identified (Fig. 10). This work confirmed that edamame soybeans can be grown in the east coast (Sciarappa et al., 2004) and provide a nutritionally rich food crops as an added benefit.

Outreach. This project has generated unique production and consumer-based marketing data on preferred Asian vegetable crops that was outreached through extension channels for farmers, advisors, and marketers (Govindasamy et al., 2007a; Simon et al., 2012). Selected results of these ongoing studies have been compiled into fact sheets and outreach literature (Ayeni et al., 2010a, 2010b, 2010c; Park et al., 2007; Sciarappa and Quinn, 2004a, 2004b). Other outreach resources, such as the worldcrops.org website
(Van Vranken, 2010), helps to connect east coast growers with emerging ethnic markets as well as individual university websites. University researchers in this specialty crop area regularly present at agricultural conferences, horticultural workshops, and on-farm tours. Our extension outreach is an attempt to strengthen the economic viability of the east coast vegetable industry while contributing to the culinary and nutritional needs and preferences of a diversity of ethnic and mainstream consumers.

Comments and conclusions. This marketdriven model has demonstrated a shift from a production paradigm approach to a marketconsumer-driven approach in focusing crop research. The combination of consumer feedback directing university testing of Asian crops worked well to quantify and target the most promising specialty ethnic vegetables, herbs, and leafy greens. Grower, advisor, and distributor response to this blend of agribusiness data and horticultural research has been highly supportive. They recognize the value 
Table 5. Mineral composition of Asian ethnic greens, herbs, and vegetables field grown in New Jersey.

\begin{tabular}{llllll}
\hline Crop names & $\% \mathrm{~N}$ & $\% \mathrm{P}$ & $\% \mathrm{~K}$ & $\% \mathrm{Ca}$ & $\% \mathrm{Mg}$ \\
\hline Indian sorrel & 4.49 & 0.96 & 7.71 & 1.92 & 1.29 \\
Radish & 5.18 & 0.34 & 4.00 & 5.58 & 0.53 \\
Red leaf amaranth & 4.49 & 0.69 & 7.7 & 4.41 & 1.17 \\
Malabar spinach & 2.76 & 0.34 & 6.22 & 6.27 & 2.57 \\
Amaranth & 4.44 & 0.61 & 7.15 & 4.80 & 1.39 \\
MeiQing bok choi & 4.50 & 0.76 & 8.25 & 4.24 & 0.51 \\
Pak choi & 4.18 & 0.53 & 6.34 & 4.72 & 0.56 \\
Sugar pea & 4.38 & 0.53 & 3.9 & 1.17 & 0.26 \\
Garlic chives & 4.06 & 0.60 & 3.73 & 1.77 & 0.49 \\
Chinese chives & 4.22 & 0.55 & 3.07 & 1.13 & 0.39 \\
\hline
\end{tabular}

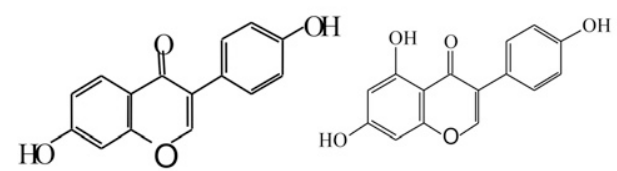

Daidzein

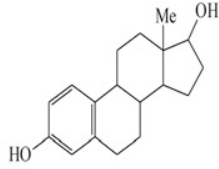

Estradial

Fig. 10. Molecular structure of edamame isoflavones compared with human estradial — Shen et al. (2011).

in surveying, selecting, and pretesting potential crops that can be grown successfully in their areas. A grower can use these results to more knowledgeably project retail sales, customer number needed, and potential profit based on his crop budgets. Similarly, a wholesaler or retailer could estimate potential costs, markups, and profits based on expected crop quantity being grown for an extended distribution chain.

These applied results help minimize production risk through improved planning, pricing, and marketing that more effectively penetrates emerging and expanding Asian markets. Such economic information, purchasing calculations, consumer preference, and research demonstration allows the grower as well as the distributer to more accurately decide on specific farm crops and better determine distribution strategies. Ultimately, the consumer may be better served with wider choices, greater availability, and fresher quality.

\section{Literature Cited}

Ayeni, A., W. Sciarappa, R. VanVranken, R. Govindasamy, V.S. Puduri, K. Pappas, J.E. Simon, F. Mangan, M. Lamberts, and G. McAvoy. 2010a. Sponge gourds or luffas [Luffa cylindrica (L.) M. Roemer and L. acutangula (L.) Roxb.]. The New Jersey Agricultural Experiment Station (NJAES) Fact Sheet, 2 pp.

Ayeni, A., R. VanVranken, W. Sciarappa, R. Govindasamy, V.S. Puduri, K. Pappas, J.E. Simon, F. Mangan, M. Lamberts, and G. McAvoy. 2010b. Chiles (Ethnic peppers): Anaheim or New Mexico pepper (Capsicum annuum L.), Aji Dulce (C. chinense Jacq.), and Jalapeno Chile (C. annuum L.), Rutgers Cooperative Extension Fact Sheet, 2 pp.

Ayeni, A., R. VanVranken, W. Sciarappa, R. Govindasamy, V.S. Puduri, K. Pappas, J.E. Simon, F. Mangan, M. Lamberts, and G. McAvoy. 2010c. Bok choys (Chinese cabbages): Bok choy/ choi, Shanghai bok choy/choi and Baby Bok Choy/Choi (Choy/Choi tops) (Brassica rapa subsp. chinensis), Rutgers Cooperative Extension Fact Sheet, 2 pp.
Bellavia, A., S.C. Larsson, M. Bottai, A. Wolk, and N. Orsini. 2013. Fruit and vegetable consumption and all-cause mortality: a dose-response analysis. Amer. J. Clin. Nutr. 98:454-459.

Block, E. 2010. Garlic and other alliums: The lore and the science. RSC Publishers, Cambridge, UK.

Cappellano, K. 2009. Influencing food choices: nutrition labeling, health claims, and front-ofthe-package labeling. Nutr. Today 44:269-273.

Chaput, J. 1998. Asian vegetables grown in Ontario. Fact Sheet Ontario Ministry of Agriculture. Order No. $98-033$.

Goldman, I.L. 2014. The future of breeding vegetables with human health functionality realities, challenges and opportunities. HortScience 49: 133-137.

Goldman, I.L. 2003. Recognition of fruits and vegetables as healthy: Vitamins and phytonutrients. HortTechnology 13:252-258.

Govindasamy, R., S. Arumugam, and I. Vellangany. 2014a. The influence of country-of-origin labeling for lentils on consumer preference: A study with reference to Sri Lanka. The IUP Journal of Marketing Management, Vol. XIII, No. 3.

Govindasamy, R., K.M. Kelley, J.E. Simon, S. Zhang, F. Mangan, W.J. Sciarappa, R.W. Van Vranken, A. Ayeni, P. Nitzsche, B. Schilling, S.J. Komar, S. Arumugam, I. Vellangany, G. McAvoy, E. Dagar, C.H. Park, W. Reichert, R. Pyne, D. Giurleo, K. Gustafson, L. Giordano, D. Byrnes, R. Juliani, and Q. Wu. 2014b. Locally grown ethnic greens and herbs: Demand assessments and production opportunities for east coast farmers. USDA-SCRI Final Report, 308 p.

Govindasamy, R., K. M. Kelley, J. E. Simon, S. Zhang, F. Mangan, W.J. Sciarappa, R. W. Van Vranken, A. Ayeni, P. Nitzsche, B. Schilling, S. J. Komar, S. Arumugam, I. Vellangany, G. McAvoy, E. Dagar, C. H. Park, W. Reichert, R. Pyne, D. Giurleo, K. Gustafson, L. Giordano, D. Byrnes, R. Juliani, and Q. Wu. 2014c. Identification of ethnic greens and herbs for the east coast United States of America: Focus group and survey methods approach. Project report was supported by the specialty crop research initiative of the National Institute of Food and Agriculture, USDA, Grant number 2009-51181-06035.

Govindasamy, R., K. M. Kelly, and V. S. Puduri. 2011. Using internet bulletin board focus group sessions to elicit consumer preferences for ethnic greens and herbs. J. Food Distrib. Res. 63(1).

Govindasamy, R., R. VanVranken, W. Sciarappa, A. Ayeni, V.S. Puduri, K. Pappas, J.E. Simon, F. Mangan, M. Lamberts, and G. McAvoy. 2010a. Consumers' shopping patterns and expenditures on ethnic produce: A case study from the eastern coastal U.S.A. J. Amer. Soc. Farm Managers and Rural Appraisers 73:36-49.

Govindasamy, R., R. VanVranken, W. Sciarappa, A. Ayeni, V.S. Puduri, K. Pappas, J.E. Simon, F. Mangan, M. Lamberts, and G. McAvoy. 2010b. Ethnic crop opportunities for growers on the east coast: A demand assessment. J. Ext 48(6). 25 Oct. 2016. <http://www.joe.org/joe/ 2010december/pdf/JOE_v48_6rb2.pdfl>

Govindasamy, R., W. Sciarappa, V.S. Puduri, R. VanVranken, A. Ayeni, K. Pappas, J.E. Simon, F. Mangan, M. Lamberts, and G. McAvoy. 2007a. A Market driven approach to ethnic crop production for the US east coast, p. 261273. In: J. Janick and A. Whipkey (eds.). The Sixth New Crops Symposium: Creating Markets for Economic Development of New Crops and New Uses. ASHS Press, Alexandria, VA.

Govindasamy, R., R. VanVranken, W. Sciarappa, A. Ayeni, V.S. Puduri, K. Pappas, J.E. Simon, F. Mangan, M. Lamberts, and G. McAvoy. 2007b. Survey methods and identification of ethnic crops for the east coast in the USA: A procedural synopsis. New Jersey Agricultural Experiment Station P-02903-1-07.

Govindasamy, R., R. VanVranken, W. Sciarappa A. Ayeni, V.S. Puduri, K. Pappas, J.E. Simon, F. Mangan, M. Lamberts, and G. McAvoy. 2007c. Demographics and the marketing of Asian and Hispanic produce in the eastern coastal U.S.A. 68 pages. NJAES P-039032-07.

Janick, J. 2003. Herbals: The connection between horticulture and medicine. HortTechnology 13 . 229-238.

Mangan, F., Z. Barros, C. Fernandes, M. Moreira, F. Finger, and G. Almeida. 2012. Developing sustainable production practices for new tropical vegetable crops for the northeastern United States. Acta Hort 936:53-60. 25 Oct. 2016. <http://www. actahort.org/books/936/936_5.htm>.

Molinar, R.H. 2012. Indigenous Asian specialty vegetables in the central valley of California. HortScience 47:835-838

Mou, B. and G. Wang. 2012. Asia's indigenous horticultural crops: An introduction. HortScience 47:819-820.

Newell-McGloughlin, M. 2008. Nutritionally improved agricultural crops. Plant Physiol. 147:939-953.

Park, C.H., P. Tannous, J.E. Simon, T.O. Kwon, W Sciarappa, L.E. Craker, R.V. Ranken, W. Kline, P.J. Nitzsche, H.R. Juliani, and R. Govindasamy. 2007. Chives and perilla, Korean greens for emerging ethnic markets, p. 228-232. In: J. Janick and A. Whipkey (eds.). The Sixth New Crops Symposium: Creating Markets for Economic Development of New Crops and New Uses. ASHS Press, Alexandria, VA.

Patel, B.S., G.K. Jayaprakasha, and A. Vikram. 2012. Indigenous crops of Asia and southeast Asia; exploring health-promoting properties. HortScience 47:821-827.

Sciarappa, W. and V. Quinn. 2004a. Edamame: The vegetable soybean: New crops for the home garden series. FS041. 25 Oct. 2016. $<$ https://njaes.rutgers. edu/pubs/publication.asp?pid=FS041 $>$.

Sciarappa, W. and V. Quinn. 2004b. International eggplants: New crops home garden series. FS043. 25 Oct. 2016. <https://njaes.rutgers.edu/pubs/ publication.asp?pid=FS043>. 
Sciarappa, W. 2003. Heritage crop research at Rutgers. Proceedings National Association of County Agricultural Agents, p. 122.

Sciarappa, W. 2001. Growing ethnic vegetables with plasticulture. Vegetable Growers News 35(4):32-33.

Puduri, V.S. and R. Govindasamy. 2011. Asian consumers' willingness to buy locally grown ethnic produce: A study from east-coast United States. J. Sustain. Agr. 35:511-521.
Shen, D., Q.L. Wu, W.J. Sciarappa, and J.E. Simon. 2011. Chromatographic fingerprints and quantitative analysis of is flavones in Tofu-type soybeans. J. Food Chem 130(4):1003-1009.

Simon, J.E., C. Park, A. Ayeni, R. Payne, P. Nitzsche, W. Sciarappa, R. VanVranken, S. Komar, E. Dager, Q. Su, B. Schilling, R. Govindasamy, and K.M. Kelley. 2012. Producing and marketing ethnic herbs and greens. New Jersey Vegetable Growers Association Annual Proceedings.
Tubene, S. 2001. Market potential for ethnic produce in the mid-Atlantic region. Maryland Cooperative Extension, University of Maryland, College Park-Eastern Shore.

U.S. Census. 2000, 2010, 2011 and 2014. United States Department of Commerce. Washington, DC

Van Vranken, R. 2010. World crops: Opportunities created by ethnically diverse communities. USDA-Research, Education and Economics Information System. Accession \#0203113. 